\title{
THE IMPLEMENTATION OF SCIENCE-BASED MODULE IN IMPROVING STUDENTS' CRITICAL THINKING SKILLS AND LEARNING OUTCOMES IN STATE SENIOR HIGH SCHOOL IN SOUTHWEST ACEH DISTRICT
}

\author{
Muhibbuddin $^{1 *}$, Soraya Ulfah ${ }^{2}$, Safrida $^{3}$, Cut Nurmaliah ${ }^{4}$ \\ 1Dr, SyiahKuala University, Banda Aceh, Indonesia, muhibbuddin@unsyiah.ac.id \\ ${ }^{2}$ SyiahKuala University, Banda Aceh, Indonesia, sorayaulfah.mpbio17@edu.unsyiah.ac.id \\ ${ }^{3}$ SyiahKuala University, Banda Aceh, Indonesia, saf_rida@unsyiah.ac.id \\ ${ }^{4}$ SyiahKuala University, Banda Aceh, Indonesia, cutnurmaliah@fkip.unsyiah.ac.id \\ ${ }^{*}$ Corresponding Author
}

\begin{abstract}
Critical thinking skills and learning outcomes are two important components in the success of the learning process. Some research results showed that students' critical thinking skills and learning outcomes are below the average minimum standard, so learning innovations are needed to overcome these problems. Implementation of scientific-based modules is one of the innovations to improve students' critical thinking skills and learning outcomes. This study aims to improve students' critical thinking skills and learning outcomes through the implementation of scientific-based modules. This is an experimental research design with one group pretest-posttest. The research subjects consisted of 148 students from two high schools. The parameters measured in this study are critical thinking skills and learning outcomes. The data of critical thinking skills and learning outcomes were analyzed using parametric statistics which tested the difference between the two average pretest scores with normalized gain ( $n$-gain) using a one-sample $t$-test. The relationship between critical thinking skills and learning outcomes was analyzed using correlation and regression tests. The results of the study showed that critical thinking skills increased by $65 \%$ and the learning outcomes by $88 \%$. The strong correlation between critical thinking skills and student learning outcomes is indicated by a value of 0.85 . It means that the implementation of scientific-based modules can improve students' critical thinking skills and learning outcomes. Besides, critical thinking skills also make a positive contribution to students' learning outcomes by $85 \%$.
\end{abstract}

Keywords: Scientific Module, Critical Thinking Skills, Learning Outcomes

\section{INTRODUCTION}

Critical thinking skills are the ability or skill of students to think logically, a strong desire to get clarity and accuracy of information (Anisa et al., 2015). According to Anderson (2004), the development of critical thinking skills makes students look for accurate information, is open-minded, tolerant of new ideas, can analyze problems well, and has high curiosity. Critical thinking skills are high-level thinking skills that lead to students' ability to solve problems to achieve learning goals. The low critical thinking skills can have an impact on the low learning outcomes of students. Learning outcomes are the ability of students to fulfill a 
stage of learning experience achievement in one basic competency (Kunandar, 2007). According to Abdurrahman (2003), learning outcomes are abilities obtained by children after going through learning activities.

Formal education institutions use specific learning outcomes assessment references. Hamalik (2005) explained that learning outcomes are the result of the learning process. Learning outcomes are represented in values or numbers that lead to cognitive, affective, and psychomotor changes. Learning outcomes are related to achievement in obtaining abilities by planned learning goals. Learning outcomes consist of cognitive, affective, and psychomotor.

The 2018 CBT test results show that the natural science mean in Aceh Province is 40.49 and the Biology score in Southwest Aceh District is 37.85. Both of these average values are still below the national mean of 53.42 (Puspendik, 2018). The low mean is caused by the use of new and unfamiliar types of questions namely HOTS (High Order Thinking Skill).

The results of preliminary observations and interviews with biology teachers in Southwest Aceh State High School in January 2019 showed that the low critical thinking skills of students were caused by the lack of students' ability to focus, analyze, and answer questions. Also, they are less proficient in assuming and drawing conclusions that lower their learning outcomes. The development of critical thinking skills and learning outcomes requires appropriate learning models, methods, and media such as scientific-based modules.

Scientific-based modules can support the learning process and improve students' critical thinking skills (Dewi, 2016). The modules can also increase students' learning interest by $80 \%$ (Wahyudi, 2017). Setyawan et al (2017) stated that the use of scientific-based modules that are adapted to the syllabus and curriculum that is effective can improve critical thinking skills. Setiyadi et al. (2017) showed that scientific-based modules can improve students' learning outcomes with classical completeness by $84.21 \%$ (high category).

Scientific modules contain and present material and scientific tasks such as observing, asking, experimenting, analyzing, and concluding. Scientific learning emphasizes the activeness of students in learning concepts through direct contact with the phenomena of everyday life to increase knowledge, learning outcomes Setyawan et al., 2017), and critical thinking skills (Dewi et al., 2016). One of the characteristics of a scientific approach is the involvement of potential cognitive processes in stimulating the development of intelligence, especially higher-order thinking skills (Hosnan, 2014).

Research on module implementation in the learning process (Sutrisno, 2016; Susilo et al., 2016; Anisa et al., 2015; Dewi et al., 2016; Budiyanto et al., 2016; Setiyadi et al., 2017; Pebruanti \& Munadi, 2015; Aktamis \& Ergin, 2008; Febriana, 2016; Kirana et al, 2018) only revealed the effect of the implementation on learning outcomes, motivation, ability to create, and science process skills. Research on the effects of implementing scientific modules on critical thinking skills is still very limited. This study was conducted to determine the effect of implementing scientific-based modules on improving critical thinking skills and learning outcomes.

\section{RESEARCH METHODOLOGY}

This study uses a one-group pretest-posttest design. The design of the experiment can be seen in Table-3.1.

Table 1. One Group Pretestt-Posttest Design

\begin{tabular}{|c|c|c|}
\hline Pre-test & Treatment & Post-tes \\
\hline $0_{1}$ & $\mathrm{X}_{1}$ & $0_{1}$ \\
\hline
\end{tabular}

Description:

01 : Test before the implementation of scientific modules

$\mathrm{X} 1$ : Treatment, the implementation of scientific modules

01 : Test after the implementation of scientific modules

The subjects of this study were 148 grade XI senior high students in Southwest Aceh District. The research was conducted for two months from July-August 2019. The data collection parameters in this study were critical thinking skills and learning outcomes. Critical thinking skills and learning outcomes are measured using objective tests that are reasonable multiple-choice questions.

\section{DATA ANALYSIS}

Students' critical thinking skills and learning outcomes data are analyzed parametrically which include tests of normality, Homogeneity, normalization of gain (n-gain), and the average two difference test. Two different 
test averages are performed using paired sample t-tests by comparing the initial ability (the results of the pretest) with the final ability (n-gain). Meanwhile, the correlation of critical thinking skills with students' learning outcomes is known through correlation and regression analysis. The data analysis process was carried out using the SPSS program.

\section{FINDINGS AND DISCUSSION}

\subsection{The improvement of Critical Thinking Skill}

Students' critical thinking skills data include the ability to provide simple explanations, build basic skills, infer, provide further explanations, and manage strategies and techniques. Figure-1 shows the improvement of students' critical thinking skills.

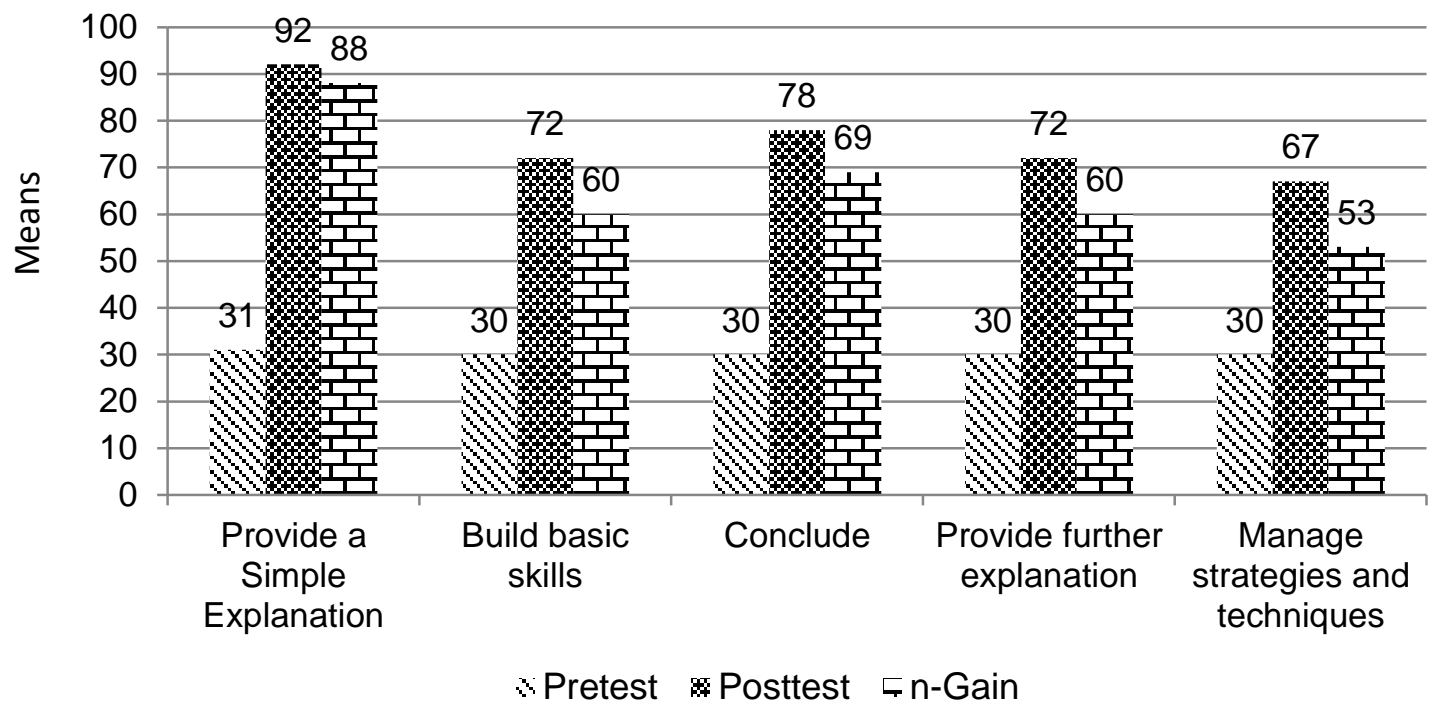

Fig 1. The means of Posttest, Pretest, and N-Gain of Competency-Based Curriculum Scores per indicator

The pretest, posttest, and n-gain of the students 'critical thinking skills (Figure-1) show that the means of the students' critical thinking skills on each indicator are different. The overall students' critical thinking skills are also significantly different (Table-2). The overall improvement in students' critical thinking skills can be seen in Figure-2.

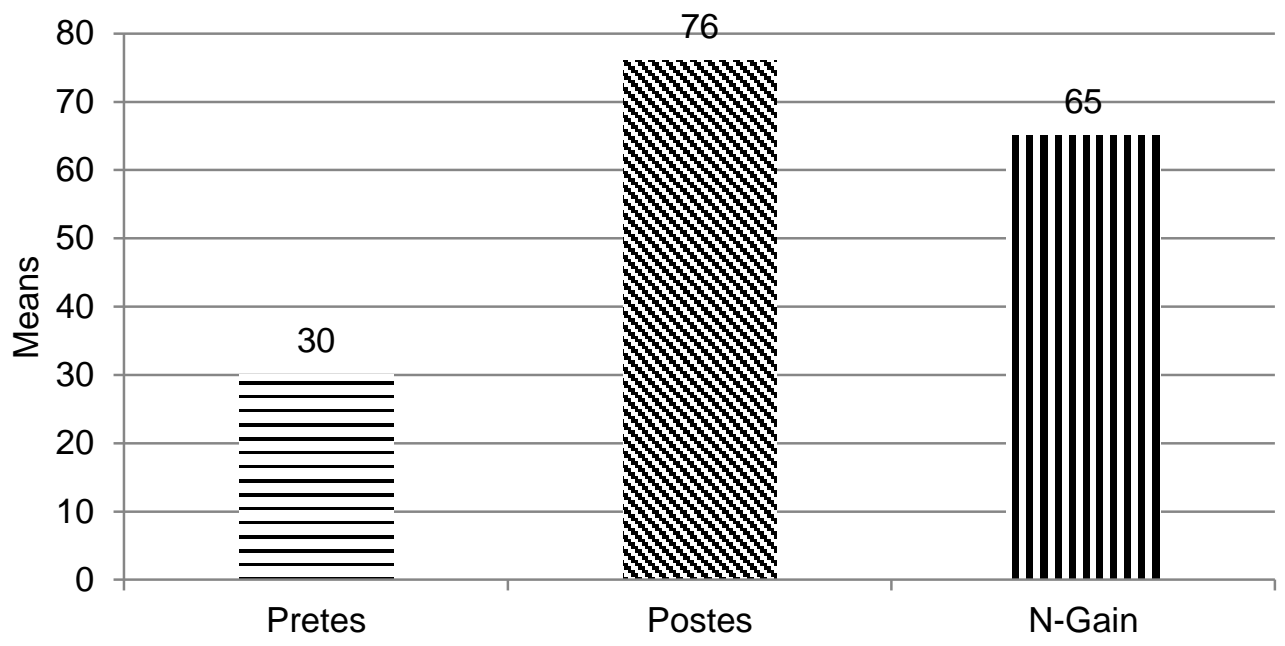

Figure-2. The Posttest, Pretest and N-Gain means of Critical thinking skill

Figure-2 shows the increase in the n-gain means of the pretest and posttest and are significantly different. The difference is seen based on the n-gain percentage of $65 \%$. The data shows that the implementation of scientific-based modules contributes well to the improvement of critical thinking skills. The recapitulation of the average test difference between the pretest score and the $\mathrm{n}$-gain is shown in Table-1. 
Table 2. Recapitulation of Mean difference test on Pretest and N-Gain scores for students' critical thinking skills.

\begin{tabular}{|c|c|c|c|c|}
\hline $\begin{array}{c}\text { Critical } \\
\text { thinking skill }\end{array}$ & Means & Normality ${ }^{\star}$ & Homogeneity & Significance ${ }^{\star \star}$ \\
\hline Pretest & 30 & $\begin{array}{c}\text { Normal } \\
\text { Sig. } 0.784 \geq 0.025\end{array}$ & \multirow{2}{*}{$\begin{array}{c}\text { Homogeneous } \\
\text { Sig. } 0.053 \geq 0.025\end{array}$} & \multirow{2}{*}{$\begin{array}{c}\text { Significant } \\
\text { Sig.0.000 } \leq 0.025\end{array}$} \\
\hline N-Gain & 65 & $\begin{array}{c}\text { Normal } \\
\text { Sig. } 0.703 \geq 0.025\end{array}$ & & \\
\hline
\end{tabular}

Description:

${ }^{*}$ ) $=$ Kolmogorov-Smornov $Z$ Test (Normal, sig $\geq 0.025$ )

$\left.{ }^{* *}\right)=$ Paired Sample Test (Significant, sig $\left.\leq 0.025\right)$

Table 2 shows a significant difference between the initial ability (pretest score) and the increase in critical thinking skills (n-gain). It means that implementing scientific-based modules in learning can improve students' critical thinking skills. The improvement is triggered by the ability of scientific-based modules to train students to find main concepts, find facts, and prove theories in the learning process. Scientific-based modules can train students to obtain or correct new knowledge, combine it with previous knowledge, collect evidence from observed objects (experiment) empirically and measurably with specific principles of reasoning (Anonymous, 2013). Direct observation of the life of individuals or groups of living things is closely related to students' critical thinking skills. Saminan et al. (2016) also suggested that students are required to think actively to become accustomed to critical thinking skills. Students must be active to ask and answer questions during the learning process so they can answer posttests easily based on the concepts they have learned. Ulandari et al. (2018) also revealed that scientific-based modules can improve the ability to think critically (the cognitive realm) because the modules respond positively to student learning and there is compatibility between scientific learning steps and the 2013 Curriculum.

\subsection{The Improvement of Learning Outcomes}

Learning outcomes data consists of initial ability (pretest score), final ability (posttest score), and improvement of learning outcomes ( $\mathrm{n}$-gain) (Figure-3).

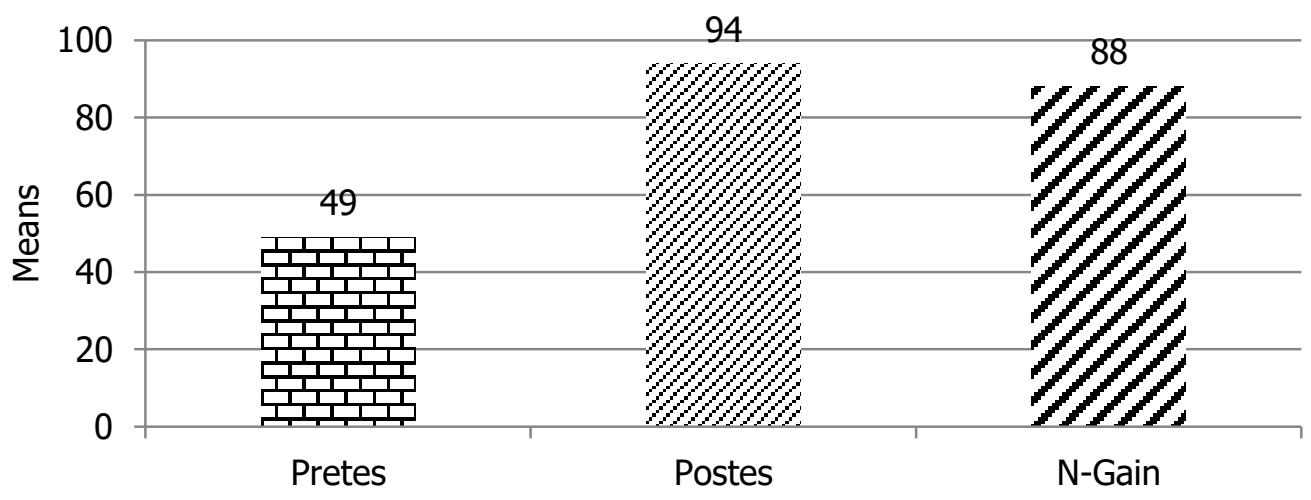

Figure-3. Means of Pretest, Posttest and N-gain of learning outcomes

Learning outcomes data (Figure-3) shows the average pretest is 49 , the average posttest is 94 , and the mean of the improvement of learning outcomes (n-gain) is $88 \%$. The mean difference test results between the pretest and the mean of the improvement of learning outcomes (n-gain) are presented in Table-3.

Table 3. Recapitulation of the Mean difference test between the Pretest and the N-Gain scores.

\begin{tabular}{|c|c|c|c|c|}
\hline $\begin{array}{c}\text { Learning } \\
\text { outcomes }\end{array}$ & Means & Normality & Homogeneity & Significance $^{* *}$ \\
\cline { 1 - 2 } Pretest & 49 & $\begin{array}{c}\text { Normal } \\
\text { Sig.1.272 } \geq 0.025\end{array}$ & $\begin{array}{c}\text { Homogeneous } \\
\text { Sig.0.057 } \geq 0.025\end{array}$ & $\begin{array}{c}\text { Significant } \\
\text { Sig. } 0.000 \leq 0.025\end{array}$ \\
\cline { 1 - 3 } N-Gain & 88 & $\begin{array}{c}\text { Normal } \\
\text { Sig. } 1.837 \geq 0.025\end{array}$ & . \\
\hline
\end{tabular}

Description: 
*) $=$ Kolmogorov-Smornov $Z$ Test (Normal, sig $\geq 0.025$ )

$\left.{ }^{* *}\right)=$ Paired Sample Test (Significant, sig $\leq 0.025$ )

The results of data analysis (Table 3.) show a significant difference between the initial ability (pretest score) and an improvement of learning outcomes (n-gain). It means that implementing scientific-based modules can improve learning outcomes. Improved learning outcomes are affected by the ability of scientific-based modules to train students to find main concepts, find facts, and prove the theories learned in the learning process. Also, HOTS questions that focus on analysis and evaluation can increase students' focus on developing thinking skills that lead to an improvement of learning outcomes. Muhafid et al. (2017) revealed that the implementation of scientific-based modules in the learning process contributed positively to the improvement of learning outcomes. Besides, it is also able to improve students' abilities in observing, asking questions, experimenting, presenting the results of reports, and answering tests given. Setiyadi et al. (2017) also showed that the implementation of scientific-based biology learning modules was very effective in increasing students' understanding in the learning process.

\subsection{The correlation between Critical Thinking Skills and Learning Outcomes}

Table 4 shows the results of the analysis of the relationship between critical thinking skills and learning outcomes.

Table 4. Recapitulation of Correlation Test between Critical thinking skills and Learning outcomes.

\begin{tabular}{|c|c|c|c|c|}
\hline Critical thinking skill & $\begin{array}{c}\text { Learning } \\
\text { outcomes }\end{array}$ & $\begin{array}{c}\text { Correlation } \\
(r)\end{array}$ & $r^{2}$ & Significance* $^{*}$ \\
\hline 75.90 & 94.30 & 0.85 & 0.72 & $\begin{array}{c}\text { Significant } \\
\text { Sig: } 0.000<0.05\end{array}$ \\
\hline
\end{tabular}

Description $^{*}$ ) $=$ t-test if sig $<0.05$

The correlation test results (Table-4) show the correlation coefficient ( $r$ ) of 0.85 and $r 2$ of 0.72 . It shows a strong relationship between critical thinking skills and learning outcomes. The improvement of learning outcomes by $72 \%(r 2=0.72)$ is believed to be influenced by the ability to think critically and the remaining $28 \%$ is influenced by other factors. Regression test results of $\ddot{Y}=0.5857 x+49.866$ (Figure-4) show that the improvement of critical thinking skills will improve the learning outcomes.

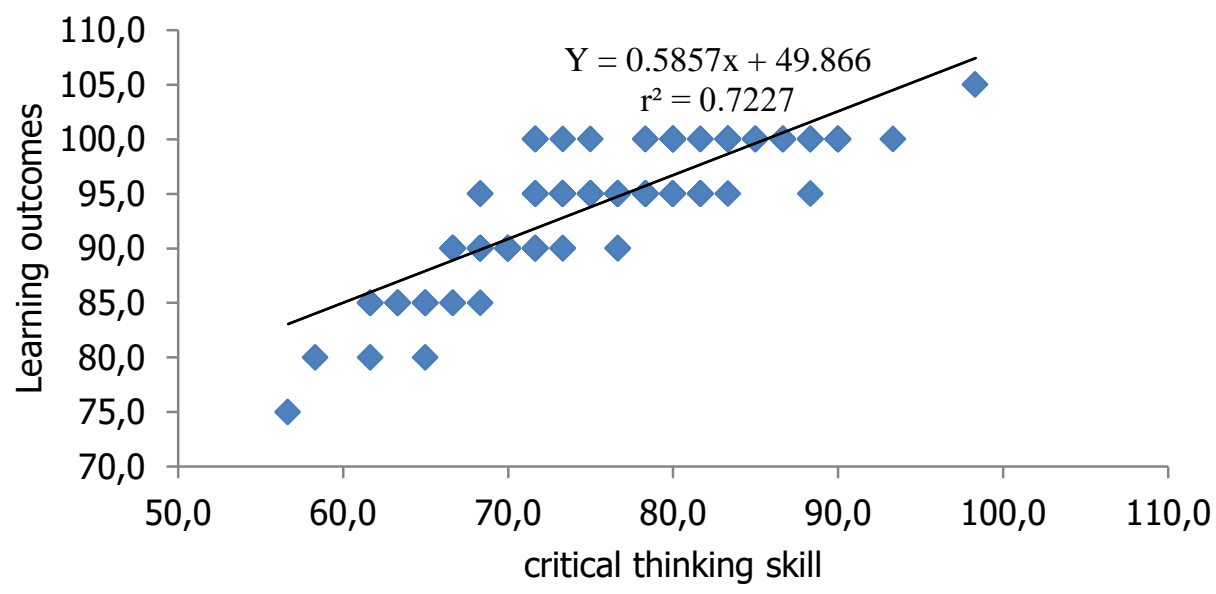

Figure 4. Regression between Students' critical thinking skills and learning outcomes

A strong correlation between students' critical thinking skills and learning outcomes shows that the skills can train and develop students' thinking abilities that have an impact on the improvement of learning outcomes. The improvement of critical thinking skills and learning outcomes is the impact of the implementation of the scientific module. Antika et al. (2017) revealed that critical thinking skills are closely related to students' learning outcomes. Critical thinking skills make students able to think critically, logically, and systematically which leads to good learning outcomes. Ramdani and Badriah (2018) also suggested the improvement of critical thinking would improve learning outcomes. Weissinger (2004) also explains that critical thinking skills can practice self-reflection, basic abilities, and the willingness to ask questions to clarify and enhance the understanding that can help students in drawing conclusions and making decisions. 


\section{RERERENCE LIST}

Abdurrahman, M. (2003). Pendidikan Bagi Anak Berkesulitan Belajar. Jakarta: PT Rineka Cipta.

Aktamis, H., \&Ergin, O. (2008). The effect of scientific process skill education on students scientific creativity, science attitudes and academic achievements. Journal: Asia Pacific Forumon Science Learning and Teaching. 9(1):1-21.

Anderson, J. A. (2004). Critical Thinking Across the Disciplines. New York: Faculty Development Seminar in New York City College of Technology.

Anonymous. 2013. Konsep Pendekatan Scientific. Jakarta: Kementrian Pendidikan dan Kebudayaan.

Anisa, Z. H.; Dwiastuti, S. \& Marjono. (2015). Peningkatan Motivasi Belajar Dan Ability Students' critical thinking Pada Materi Ekosistem Melalui Penerapan Model Inkuiri Terbimbing. Bioedukasi. 6(2):7985.

Antika, L.T.A.D.; Corebima \& Zubaidah, S. (2017). Hubungan Antara Critical thinking skill dengan Learning outcomes Biologi Dengan Model Reading-Concept Map-Think Pair Share (Remap TPS). Science Education National Conference. Madura: Universitas Islam Madura Pamekasan.

Budiyanto, M.A.K; Waluyo, L \& Mokhtar A. (2016). Implementasi Pendekatan Saintifik dalam Pembelajaran di Pendidikan Dasar di Malang. Proceeding Biology Education Conference, 13(1): 46-51.

Dewi, I.S; Sunarno, W \& Dwiastuti, S. (2016). Profil Peningkatan Ability Berpikir Kritis Siswa SMPN 1 Weru Melalui Implementasi Modul IPA Menggunakan Scientific modules. Prosiding Seminar Nasional Pendidikan Sains (SNPS). Surakarta: Universitas Sebelas Maret.

Febriana, Y. (2016). Penerapan Pendekatan Saintifik Untuk Meningkatkan Skill Proses Sains Di Kelas IV SD. Jurnal Pendidikan Guru Sekolah Dasar, 1(1):142-155.

Hamalik, O. (2005). Perencanaan Pengajaran Berdasarkan Pendekatan Sistem. Jakarta: PT. Bumi Aksara.

Hosnan, (2014). Pendekatan Saintifik Dan Kontekstual Dalam Pembelajaran Abad 21 Kunci Sukses Implementasi Kurikulum 2013. Bogor: Ghalia Indonesia.

Kirana, F.C, Halim. A \& Rahwanto A. Pengembangan Dan Implementasi Modul Fisika Berbasis Saintifik pada Materi Alat Optik Untuk Meningkatkan KPS Siswa Di SMA Negeri 5 Banda Aceh. Jurnal Pendidikan Sains Indonesia. 6(2):107-111.

Kunandar. (2007). Guru Profesional: Implementasi Kurikulum Tingkat Satuan Pendidikan (KTSP) dan Sukses dalam Sertifikasi Guru. Jakarta:Rajagrafindo Persada.

Muhafid, E.A.; Suparmi; \& Sunarno, W. (2017). Pengembangan Modul IPA Berbasis Saintifik Pada Tema Polusi Udara Untuk Meningkatkan Motivasi Belajar Dan Skill Proses Sains (KPS) Students Di SMP/MTs Kelas VIII. Jurnal Inkuiri, 6(2): 83-96.

Pebruanti, L \& Munadi, S.(2015). Peningkatan Motivasi Dan Learning outcomes Pada MataPelajaran Pemograman Dasar Menggunakan Modul Di SMKN 2 Sumbawa. Jurnal Pendidikan Vokasi, 5(3): 365-376.

Ramdani, D. \& Badriah, L. (2018). Correlation Antara Ability Berpikir Kritis Dengan Learning outcomes Students Melalui Model Pembelajaran Inkuiri Terbimbing Berbasis Blended Learning Pada Materi Sistem Respirasi Manusia. Jurnal Bio Educatio, 3(2):37-44.

Saminan, F.N.; Gani A. \& Safitri, R. (2016). Peningkatan Critical thinking skill Dan Sikap Ilmiah Students Dengan Menggunakan Model Cooperative Inquiry Labs (CIL) Pada Materi Suhu Dan Kalor. Jurnal Pendidikan Sains Indonesia, 4(2):171-179.

Setiyadi, M.W.; Ismail, \& Hamsu. A. G. (2017). Pengembangan Modul Pembelajaran Biologi Berbasis Pendekatan Saintifik Untuk Meningkatkan Learning outcomes Students. Journal of Educational Science and Technology (EST). 3(2):102- 112.

Setiyadi, M.W.; Ismail \& Hamsu. A.G. (2017). Pengembangan Modul Pembelajaran Biologi Berbasis Pendekatan Saintifik Untuk Meningkatkan Learning outcomes Students. Journal of Educational Science and Technology (EST), 3(2):102-112. 
Setyawan, D. N.; Aminah, N. S. \& Sarwanto. (2017). The Using of Scientific Based Physics Module in Learning to Enhance High School Students Critical Thinking Skills on Rotation Dynamics and Equilibrium of Rigid Body. Journal of Education and Learning, 11(2):213-218.

Susilo. A., Siswandari \& Bandi. (2016). Pengembangan Modul Berbasis Pembelajaran SaintifikUntuk Peningkatan Ability Mencipta Siswa DalamProses Pembelajaran Akuntansi Siswa Kelas Xii SMA N 1 Slogohimo 2014. Jurnal Pendidikan IImu Sosial. 26(1): 50-55.

Sutrisno, V.L.P \& Siswanto, B.T. (2016). Faktor-Faktor yang Mempengaruhi Learning outcomes SiswaPada Pembelajaran Praktik Kelistrikan Otomotif SMK Di Kota Yogyakarta. Jurnal Pendidikan Vokasi. 6(1):111-120.

Ulandari, S.F.; Wahyuni, S. \& Bachtiar. R.W. (2018). Pengembangan Scientific-based modules Untuk Melatih Ability Berpikir Kritis Pada Materi Gerak Harmonis Di SMAN Balung. Jurnal Pembelajaran Fisika, 7(1):15-21.

Wahyudi. (2017). Analisis Kontribusi Sikap Ilmiah, Motivasi Belajar Dan Kemandirianbelajar Terhadap Prestasi Belajar Mahastudents Prodi Pendidikan Fisika Stkip Pgri Pontianak. Jurnal Edukasi Matematika dan Sains, 1(2):20-31.

Weissinger, P.A. (2004). Critical Thinking, Metacognition, and Problem-based Learning. Enhanching Thinking through Problem-based Learning Approaches. International Perspectives. Singapore: Cengage Learning. 